\title{
A comparative study of the improvement after different self-assessment methods of tooth preparation
}

\author{
JungHan Kim ${ }^{1,2}$, Keunbada Son ${ }^{2,3}$, Kyu-Bok Lee ${ }^{1,2 *}$ \\ 'Department of Prosthodontics, School of Dentistry, Kyungpook National University, Daegu, Republic of Korea \\ ${ }^{2}$ Advanced Dental Device Development Institute, Kyungpook National University, Daegu, Republic of Korea \\ ${ }^{3}$ Department of Dental Science, Graduate School, Kyungpook National University, Daegu, Republic of Korea
}

Purpose: The purpose of this study was to compare the degree of tooth preparation abilities of students according to three selfassessment methods. Materials and Methods: forty-eight sophomores in Kyungpook National University College of Dentistry were divided into three experimental groups. Students performed tooth preparation of the left mandibular first molar for full gold crown. They performed self-assessment using the three methods (visual, digital, and putty index self-assessment group), and reperformed tooth preparation. An intraoral scanner was used to scan each tooth model (prepared tooth and unprepared tooth), and data were acquired in standard tessellation language (STL) file format. The STL files of prepared tooth and unprepared tooth were superimposed using the 3-dimensional analysis software (Geomagic control X). And the reduction amount was measured. In the statistical analysis, all values of reduction amount were analyzed with the Wilcoxon signed rank test and Kruskal-Wallis test $(\alpha=0.05)$. Results: The three self-assessment methods showed statistically significant differences $(P<0.001)$. The putty index self-assessment group showed the highest reduction in error than the digital self-assessment method. Conclusion: Within limitations of this study, students showed significant differences in improvement of tooth preparation ability according to the three self-evaluation methods.

(J Dent Rehabil Appl Sci 2019;35(4):220-7)

Key words: dental education; self-assessment; crown preparation; CAD/CAM; three-dimensional analysis

\section{Introduction}

In preclinical dental education, dental students are trained and evaluated through various hands-on training sessions. Maintenance of the amount of standard reduction according to prosthesis type is one of the significant evaluation factors. Furness et al. ${ }^{1}$ have reported that the lack of occlusal surface clearance is a representative critical error that prevents adequate prosthesis production. Therefore, dental students require training in preclinical practice to become pro-

\footnotetext{
*Correspondence to: Kyu-Bok Lee

Professor, Department of Prosthodontics, School of Dentistry, Advanced Dental Device Development Institute, Kyungpook National University,

2177 Dalgubul-daero, Jung-gu, Daegu, 41940, Republic of Korea

Tel: +82-53-600-7674, Fax: +82-53-427-0778, E-mail: kblee@knu.ac.kr

Received: October 7, 2019/Last Revision: November 1, 2019/Accepted: November

11,2019
}

fessional dentists. In this practical exercise, students are usually assessed by faculty members. During the evaluation process, students have complained about subjective evaluation, and conduct practice with the sole aim to achieve high test scores; ${ }^{2}$ moreover, various studies have pointed out the limitations of subjective evaluation. $^{3}$

Recently, the evaluation software of fixed dental practice evaluation using computer-aided design and computer-aided manufacturing (CAD/CAM) has been widely used. ${ }^{4-10}$ Compared to traditional learn-

Copyright@ 2019 The Korean Academy of Stomatognathic Function and Occlusion. (c) It is identical to Creative Commons Non-Commercial License. 
ing tools, color mapping for tooth preparation using scanning can provide useful information to students concerning the overall reduction amount. Renne et $\mathrm{al}^{2}$ have reported that evaluation using CAD/CAM software has an important advantage of enabling students to work independently. Use of software as a self-assessment tool by students allows learning independent of time. Several previous studies have reported that evaluation using $\mathrm{CAD} / \mathrm{CAM}$ software is objective and accurate. ${ }^{4-12}$ However, another report has indicated that evaluation of clinically critical errors is not possible using software alone as an evaluation tool. ${ }^{1}$ In addition to digital assessment, students should be able to perform self-assessment on their own. Mays and Levine ${ }^{12}$ have reported criteria of the Commission on Dental Accreditation (CODA)'s accreditation standards for dental schools of the requirement of graduates to demonstrate selfassessment ability including attaining professional competencies and professional values and capacities associated with self-directed lifelong learning, and stressed the importance of lifelong self-assessment even in dentists after graduation; since dental college students have difficulty with self-evaluation on their own, appropriate tools for self-evaluation in dental college practice are needed. ${ }^{13}$

A variety of tools are needed to ensure that students can conduct self-assessments efficiently throughout the preclinical fixed prosthodontics' course. The purpose of this study was to compare the students' ability to improve tooth preparation according to various self-assessment methods. The null hypothesis of the study is that there is no difference in tooth-removal improvement based on the three methods.

\section{Materials and Methods}

This study was approved by the Institutional Review Board of Kyungpook National University Dental Hospital (KNUDH-2018-03-004). A total of forty-eight sophomores in Kyungpook National University College of Dentistry who were registered as a part of the preclinical fixed prosthodontics course and agreed to participate in the experiment were included. In all students, tooth preparation of \#19 was performed using a plastic resin tooth on a dental typodont (Nissin Dental Products, Kyoto, Japan) and a full gold crown was obtained in one hour. Subsequently, the students were randomly divided into three groups to evaluate their tooth preparation according to three different methods used; in total, forty-eight resin teeth were scanned using an intraoral scanner (CS3600, Carestream Dental, Atlanta, USA). One investigator (JungHan Kim) scanned all the teeth that were initially prepared, in order to reduce operator error. The scan data were saved in standard tessellation language (STL) file format and submitted for 3-dimensional (3D) analysis.

Self-assessment education was performed by all students after the first preparation was obtained. The participants were divided into three groups (visual, digital, and putty index self-assessment group) according to the self-assessment method used. After receiving detailed explanation of the self-assessment method by a skilled operator (JungHan Kim), each group was trained in self-assessment : The visual
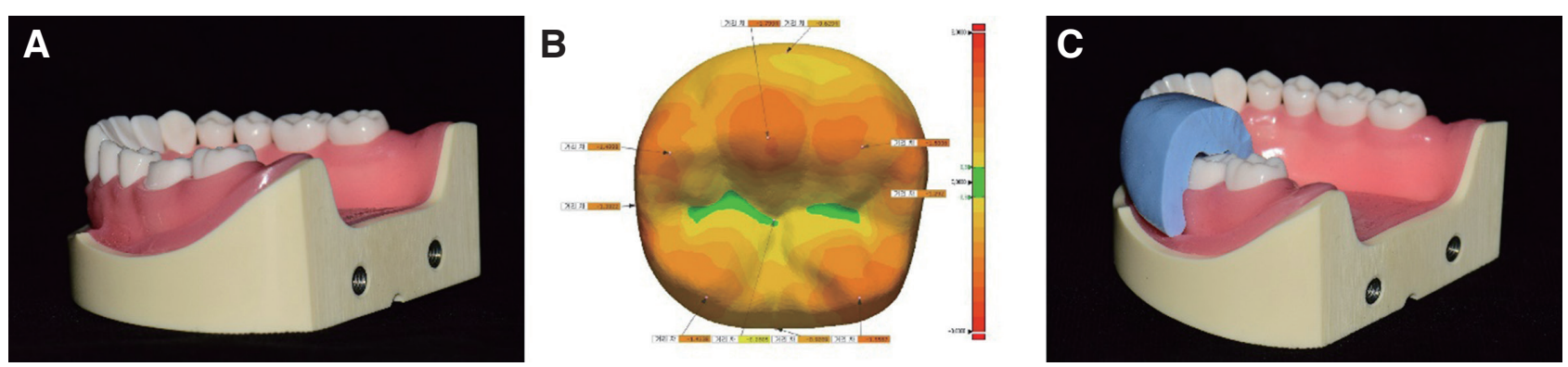

Fig. 1. Three different self-assessment methods. (A) Dental typodont for visual self-assessment, (B) Color difference map for digital self-assessment, (C) Dental typodont with putty index for putty index self-assessment. 
self-assessment group performed a traditional assessment method comprising visual assessment without teaching tools depending on the crown-reduction criteria for the gold crown which was taught at class (Fig. 1A); the digital self-assessment group conducted digital assessment with color difference mapping after receiving preliminary education on analysis of digital evaluation data (Fig. 1B) since they had not received prior education on this topic in the dental college classroom; the putty index self-assessment group conducted self-assessment using the putty index, which is widely used in the fixed prosthodontics' course (Fig. 1C). After completion of self-assessment based on the different methods using the same typodont condition of the first preparation, the second tooth preparation of \#19 was performed by the students. Subsequently, all the prepared teeth were scanned by one operator with the intraoral scanner in the same manner as that for the first tooth preparation, and the scan data were saved in the STL file format for 3D analysis.

In order to evaluate the specificity of improvement of the different groups, the degree of development was evaluated as follows. The unprepared tooth (\# 19) was scanned using the intraoral scanner to obtain the STL file (Fig. 2A). The STL file of the prepared tooth (Fig. 2B) was superimposed with the STL file of the unprepared tooth using 3D analysis software (Geomagic control X, Rock Hill, South Carolina, USA) (Fig. 2C). Only the under subsections of the dental typodont tooth (\# 19) were correctly superimposed by optimal alignment process (bestfit alignment) (Fig. 2C). After superimposition, the three cusps of the functional cusp, two cusps of the non-functional cusp, and four axis walls were used as measurement points; the reduction amount at each point was measured (functional cusp: red points, non-functional cusp: purple points, axis wall: green points) (Fig. 2D). The selected points were measured for the distance between the prepared and unprepared teeth (Fig. 2D). All measurements were performed in the same way for both primary and secondary tooth preparations. The amount of reference criteria of the functional cusp slope was set to $1.5 \mathrm{~mm}$, while its non-functional cusp slope and the axial wall were set to $1.2 \mathrm{~mm}$ and one $\mathrm{mm}$, respectively. For the purpose of this study, attaining values closer to criteria reduction at nine points reflected increasing student's ability to prepare the tooth.

All data were analyzed using statistical software (IBM SPSS Statistics v23.0; IBM Corp, Armonk, New York, USA) $(\alpha=0.05)$. Wilcoxon signed rank test was used to measure whether there was improvement of the student's tooth preparation for each assessment method. Kruskal-Wallis H Test was used to determine the difference among the three methods.
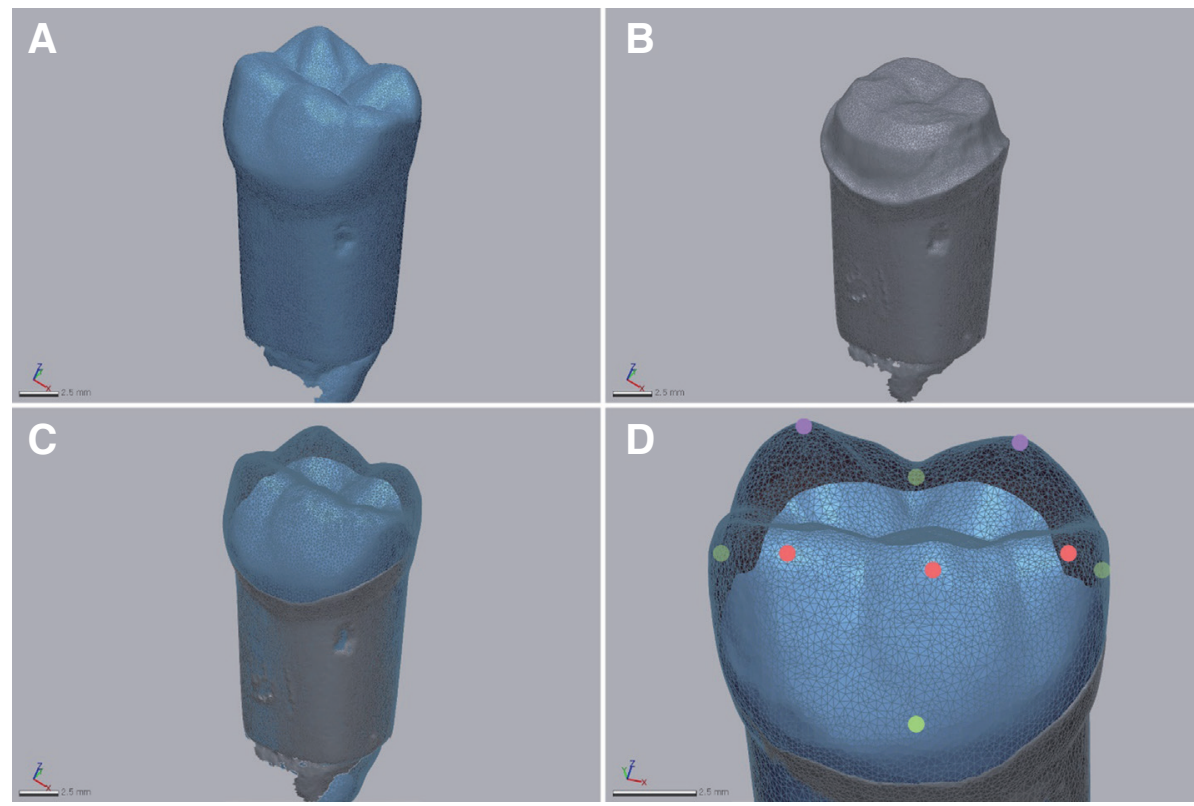

Fig. 2. Digital evaluation process by superimposition of STL files. (A) STL file of unprepared tooth, (B) STL file of prepared tooth, (C) Superimposition of STL files, (D) Reduction measurement points (functional cusp: red, non-functional cusp: purple, axis wall: green). 


\section{Results}

The three self-assessment methods showed statistically significant differences $(P<0.001)$. Tables 1 to 4 show the reduction errors (the difference between the actual reduction and the criteria value of reduction) before and after the self-assessment. And the tables confirmed that there was a significant reduction in reduction error through self-assessment. The results of each method were compared with four criteria of the functional cusp slope (Table 1), nonfunctional cusp slope (Table 2), axial walls (Table 3), and total reduction (Table 4).

First, in the functional cusp slope, with criteria val-

Table 1. Improvement comparison after tooth preparation using three self-assessment methods for functional cusp slope

\begin{tabular}{cccc}
\hline & Visual & Digital & Putty index \\
Assessment & & Reduction error value (Mean, mm) & \\
\hline Before & $0.4521 \pm 0.3497$ & $0.4464 \pm 0.2860$ & $0.4552 \pm 0.3649$ \\
After & $0.3574 \pm 0.2486$ & $0.3943 \pm 0.5714$ & $0.2966 \pm 0.1953$ \\
$P$ & 0.31 & 0.063 & $0.017^{*}$ \\
\hline
\end{tabular}

$* P<0.05$; Wilcoxon signed rank test.

Table 2. Improvement comparison after tooth preparation using three self-assessment methods for non-functional cusp slope

\begin{tabular}{cccc}
\hline & Visual & Digital & Putty index \\
Assessment & & Reduction error value (Mean, mm) & $0.3158 \pm 0.3178$ \\
Before & $0.3262 \pm 0.3132$ & $0.3997 \pm 0.3750$ & $0.3004 \pm 0.2435$ \\
After & $0.4410 \pm 0.2726$ & $0.3526 \pm 0.2682$ & 0.94 \\
$P$ & $0.03^{*}$ & 0.94 & \\
\hline
\end{tabular}

$* P<0.05$; Wilcoxon signed rank test.

Table 3. Improvement comparison after tooth preparation using three self-assessment methods for the axial wall

\begin{tabular}{cccc}
\hline & Visual & Digital & Putty index \\
Assessment & & Reduction error value (Mean, mm) & \\
\hline Before & $0.4307 \pm 0.2335$ & $0.4783 \pm 0.4338$ & $0.4365 \pm 0.2709$ \\
After & $0.3993 \pm 0.4694$ & $0.3444 \pm 0.2736$ & $0.3383 \pm 0.3174$ \\
$P$ & 0.084 & $0.046^{*}$ & $0.018^{*}$ \\
\hline
\end{tabular}

$* P<0.05$; Wilcoxon signed rank test.

Table 4. Improvement comparison after tooth preparation using three self-assessment methods for total reduction

\begin{tabular}{cccc}
\hline & Visual & Digital & Putty index \\
Assessment & & Reduction error value (Mean, mm) & \\
\hline Before & $0.4146 \pm 0.2963$ & $0.4502 \pm 0.3758$ & $0.4159 \pm 0.3177$ \\
After & $0.3946 \pm 0.3667$ & $0.3628 \pm 0.3955$ & $0.3160 \pm 0.2649$ \\
$P$ & 0.319 & $0.018^{*}$ & $0.002^{*}$ \\
\hline
\end{tabular}

$* P<0.05$; Wilcoxon signed rank test. 
ue of $1.5 \mathrm{~mm}$, the reduction error value of visual selfassessment was $0.4521 \mathrm{~mm}$ in the first preparation and $0.3574 \mathrm{~mm}$ in the second preparation. The mean value was decreased, and there was no statistically significant difference $(P=0.31)$. In the second group of digital self-assessment methods, the reduction error value was $0.4464 \mathrm{~mm}$ in the first preparation and $0.3943 \mathrm{~mm}$ in the second preparation after the evaluation. The mean value was decreased, and there was no statistically significant difference $(P=0.063)$. In the third group of Putty index self-assessment method, the mean reduction error value was $0.4552 \mathrm{~mm}$ in the first preparation and $0.2966 \mathrm{~mm}$ in the second preparation, with statistical significance $(P=0.017)$.

With regard to the non-functional cusp slope, with a value of $1.2 \mathrm{~mm}$, the reduction error value of visual self-assessment was $0.3262 \mathrm{~mm}$ in the first preparation and $0.4410 \mathrm{~mm}$ in the second preparation, with statistical significance $(P=0.03)$. In the second group of digital self-assessment methods, the reduction error value was $0.3997 \mathrm{~mm}$ in the first preparation and $0.3526 \mathrm{~mm}$ in the second preparation after the evaluation. The mean value was decreased, without significant difference $(P=0.94)$. In the Putty index self-assessment method, the reduction error value was $0.3158 \mathrm{~mm}$ in the first preparation and $0.3004 \mathrm{~mm}$ in the second preparation after the evaluation, and there was no statistically significant difference $(P=0.94)$.

With regard to the axial walls, with a criteria value of $1.0 \mathrm{~mm}$, the reduction error value of visual selfassessment was $0.4307 \mathrm{~mm}$ in the first preparation and $0.3993 \mathrm{~mm}$ in the second preparation. The mean value was decreased, with no statistically significant difference $(P=0.084)$. In the second group of digital self-assessment methods, the reduction error value was $0.4783 \mathrm{~mm}$ in the first preparation and 0.3444 $\mathrm{mm}$ in the second preparation after the evaluation. The mean value was decreased with statistical significance $(P=0.046)$. In the Putty index self-assessment method, the reduction error value was $0.4365 \mathrm{~mm}$ in the first preparation and $0.3383 \mathrm{~mm}$ in the second preparation after the evaluation, with statistical significance $(P=0.018)$.

Finally, with regard to the visual self-assessment method, the reduction error value of total reduction at a criteria value of $1.0 \mathrm{~mm}$ was $0.4146 \mathrm{~mm}$ in the first preparation and $0.3946 \mathrm{~mm}$ in the second preparation; there was no statistically significant difference $(P=0.319)$. In the second group of digital self-assessment methods, the reduction error value was $0.4502 \mathrm{~mm}$ in the first preparation and 0.3628 $\mathrm{mm}$ in the second preparation. The mean value was decreased, with statistical significance $(P=0.018)$. In the third group of putty index self-assessment method, the reduction error value was $0.4159 \mathrm{~mm}$ in the first preparation and $0.3160 \mathrm{~mm}$ in the second preparation, with statistical significance $(P=0.002)$.

\section{Discussion}

Based on the statistical results of this study, the null hypothesis was rejected. There was a difference in the degree of improvement after students' tooth preparation, according to the three self-assessment methods. In the first group of visual evaluation, the tooth preparation improvement was statistically significant only in the comparison using the axial wall as a reference point. Non-functional cusp slope indicated a tendency of increase in the amount of preparation. Overall, visual assessment without any self-assessment tools is not expected to improve the ability to prepare the tooth. Even a skilled clinician is unable to analyze the amount of reduction using only his or her naked eyes. Therefore, visual assessment without any tools may not be suitable for continuous self-assessment in sophomore dental students.

The second group of digital self-assessment using color difference mapping showed statistically improved results of the axial walls and total reduction criteria. Digital assessment through color difference mapping that expresses over-reduction and underreduction based on color standard, is expected to show improved performance for all criteria, because it provides the total amount of reduced teeth rather than normal 2D-images. However, in this study, we observed improved results for only two of the four criteria. These results suggested that students were not familiar with digital methods.

The third group of putty index showed statistically 
improved results for criteria of the functional cusp, axial wall, and total reduction. The results indicated the most improved tooth preparation ability among the three approaches. Unlike the digital method, putty index only reflects the amount of reduction in a specific section. Despite these drawbacks, this group attained highest improvement, which could be explained by the fact that students were already familiarized with using putty index in the fixed prosthodontics course before participating in the experiment.

Digital-based color difference mapping is not a regular self-assessment tool used in fixed prosthodontics' courses, and all students received training of one hour's duration before performing self-assessment. Zitzmann et al. ${ }^{14}$ reported that students who were initially introduced to both digital and traditional methods simultaneously, learned the techniques easily and preferred the digital procedure; moreover, achieving a certain level of skill took a shorter time under the digital method, which indicates that digital education should be introduced early in the curriculum of dental schools. ${ }^{14}$ Further study including students exposed to putty index and digital color difference mapping at the same rate is necessary to compare the improvement of tooth preparation abilities according to the two methods.

And the limitation in presented study suggest that because the participants are students, the variation in the tooth preparation ability and the number of exercises can be much larger than the variation in the three self-evaluation methods. Therefore, further study is needed according to the variation of tooth preparation ability and the number of exercises of each student.

\section{Conclusion}

Within the limitations of our study, students showed significant differences in improvement of tooth preparation ability according to the three selfevaluation methods used. In addition, self-assessment using the putty index showed the highest level of improvement among the three methods. Digital self-assessment also revealed the students' improved tooth preparation abilities.

\section{Acknowledgements}

The authors thank the forty-eight sophomore participants at Kyungpook National University College of Dentistry for their time and contribution to the study. This work was supported by the Technology Innovation Program (or Industrial Strategic Technology Development Program (10077743, The development of the handpiece design for the air turbine and root canal treatment) funded By the Ministry of Trade, Industry \& Energy (MOTIE, Korea); and Industrial Strategic Technology Development Program (10062635, New hybrid milling machine with a resolution of less than $10 \mu \mathrm{m}$ development, using open CAD/CAM S/W integrated platforms for one-day prosthetic treatment of 3D smart medical care system) funded By the Ministry of Trade, Industry \& Energy (MOTIE, Korea); and Korea Institute for Advancement of Technology (KIAT) through the National Innovation Cluster R\&D program (P0006691).

\section{ORCID}

JungHan Kim https://orcid.org/0000-0001-8379-152X Keunbada Son https://orcid.org/0000-0002-3177-8005

Kyu-Bok Lee https://orcid.org/0000-0002-1838-7229

\section{References}

1. Furness AR, Callan RS, Mackert JR Jr, Mollica AG. Limitations of surface mapping technology in accurately identifying critical errors in dental students' crown preparations. J Dent Educ 2018;82:69-75.

2. Renne WG, McGill ST, Mennito AS, Wolf BJ, Marlow NM, Shaftman S, Holmes JR. E4D Compare software: an alternative to faculty grading in dental education. J Dent Educ 2013;77:168-75.

3. Mays KA, Crisp HA, Vos P. Utilizing CAD/CAM to measure total occlusal convergence of preclinical dental students' crown preparations. J Dent Educ 2016;80:100-7.

4. Callan RS, Cooper JR, Young NB, Mollica AG, Furness AR, Looney SW. Inter- and intrarater reliabil- 
ity using two different software versions of E4D Compare. J Dent Educ 2015;79:711-8.

5. Callan RS, Blalock JS, Cooper, JR, Coleman JF, Looney SW. Reliability of CAD CAM technology in assessing crown preparations in a preclinical dental school environment. J Dent Educ 2014;78:4050.

6. Callan RS, Haywood VB, Cooper JR, Furness AR, Looney SW. The validity of using E4D Compare's "\% comparison" to assess crown preparations in preclinical dental education. J Dent Educ 2015;79: 1445-51.

7. Tiu J, Cheng E, Hung TC, Yu CC, Lin T, Schwass D, Al-Amleh B. Effectiveness of crown preparation assessment software as an educational tool in simulation clinic: A pilot study. J Dent Educ 2016;80: 1004-11.

8. Callan RS, Cooper JR, Young NB, Mollica AG, Furness AR, Looney SW. Effect of employing different typodonts when using E4D compare for dental student assessment. J Dent Educ 2015;79:705-10.

9. Kateeb ET, Kamal MS, Kadamani AM, Abu Hantash RO, Abu Arqoub MM. Utilising an innovative digital software to grade pre-clinical crown preparation exercise. Eur J Dent Educ 2017:21:22027.

10. Liu L, Li J, Yuan S, Wang T, Chu F, Lu X, Hu J, Wang C, Yan B, Wang L. Evaluating the effectiveness of a preclinical practice of tooth preparation using digital training system: A randomized controlled trial. Eur J Dent Educ 2018;22:e679-86.

11. Kozarovska A, Larsson C. Implementation of a digital preparation validation tool in dental skills laboratory training. Eur J Dent Educ 2018;22:11521.

12. Mays KA, Levine E. Dental students' self-assessment of operative preparations using CAD/CAM: a preliminary analysis. J Dent Educ 2014;78:167380.

13. Park CF, Sheinbaum JM, Tamada Y, Chandiramani R, Lian L, Lee C, Da Silva J, Ishikawa-Nagai S. Dental students' perceptions of digital assessment software for preclinical tooth preparation exercises. J Dent Educ 2017;81:597-603.

14. Zitzmann NU, Kovaltschuk I, Lenherr P, Dedem P, Joda T. Dental students' perceptions of digital and conventional impression techniques: A randomized controlled trial. J Dent Educ 2017;81:1227-32. 


\section{치아 삭제의 다른 자가 평가 방법 후 개선에 대한 비교 연구}

\section{김정한 ${ }^{1,2}$, 손큰바다 ${ }^{2,3}$, 이규복 ${ }^{1,2 *}$}

${ }^{1}$ 경북대학교 치과대학 치과보철학교실

${ }^{2}$ 경북대학교 첨단치과의료기기개발연구소

${ }^{3}$ 경북대학교 대학원 치의과학과

목적: 이 연구의 목적은 세 가지 자가 평가 방법에 따라 치의학전문대학원 학생들의 치아 삭제 능력의 향상 정도를 비교 하는 것이다.

연구 재료 및 방법: 경북대학교 치의학전문대학원의 2학년 48명 학생을 대상으로 3 개의 실험 그룹으로 나누었다. 금관 (gold crown)제작을 위한 좌측 하악 제1대구치의 치아삭제를 수행하였다. 세 가지 자가 평가 방법(시각적, 디지털, putty index 자가 평가 그룹)을 사용하여 자가 평가를 수행하고, 치아 삭제를 다시 수행했다. 구강 스캐너를 사용하여 각 치아 (삭제된 치아 및 삭제되지 않은 치아)를 스캔하고 standard tessellation language (STL) 파일 형식으로 데이터를 저장하였 다. 삭제된 치아와 삭제되지 않은 치아의 STL 파일은 3 차원 분석 소프트웨어(Geomagic control X)를 사용하여 중첩되 었다. 그리고 삭제량을 측정했다. 통계적 분석에서, 삭제량의 모든 값은 Wilcoxon signed rank 및 Kruskal-Wallis 테스트 로 분석하였다 $(\alpha=0.05)$.

결과: 세 가지 자체 평가 방법은 통계적으로 유의한 차이를 나타냈다 $(P<0.001)$. putty index 자가 평가 그룹은 디지털 자가 평가 방법보다 교육 후 오차의 감소가 더 컸다.

결론: 이 연구의 한계 내에서, 학생들은 세 가지 자기 평가 방법에 따라 치아 삭제 능력의 개선에 유의한 차이가 있음을 보였다.

(구강회복응용과학지 2019;35(4):220-7)

주요어: 치과 교육; 자기 평가; 치아 삭제; 캐드/캠; 3 차원 분석

*교신저자: 이규복

(41940)대구광역시 중구 달구벌대로 2177 경북대학교 치과대학 보철학교실

Tel: 053-600-7674 | Fax: 053-427-0778 | E-mail: kblee@knu.ac. kr

접수일: 2019년 10월 7일 | 수정일: 2019년 11월 1일 | 채택일: 2019년 11월 11일 